\title{
Evaluation of the bioformulation of potent native strains of Trichoderma spp. against the foot rot/gummosis of Kinnow mandarin
}

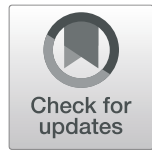

Ajay Kumar Choudhary ${ }^{1,2^{*}}$, Narinder Singh ${ }^{3}$ and Daljeet Singh ${ }^{3}$

\begin{abstract}
Background: Foot rot/gummosis of citrus, caused by Phytophthora spp., is the most important disease of citrus, responsible for the yield losses of 10 to $30 \%$ in fruit production in major citrus growing countries. Considering the burden of disease, the present study was undertaken to evaluate different native potent strains of Trichoderma spp. against the foot rot/gummosis of citrus.

Results: Based on molecular characteristics, i.e., ITS ribosomal DNA sequence analysis, 3 isolates of Phytophthora nicotianae var. parasitica and 7 isolates of Trichoderma (6 isolates of T. asperellum and one of T. harzianum) were identified. Trichoderma isolates and Metalaxyl-M + Mancozeb were used to assess antagonistic activity against the foot rot/gummosis under field conditions. T. asperellum T20 mutant reduced gummosis lesion size (95.67\%), improved feeder root density $\left(0.0236 \mathrm{~cm}^{3}\right)$, increased number (990.16), and yield of fruits (168.83 kg).

Conclusions: The talc-based bioformulation of T20 mutant (T. asperellum) strain, used as a soil treatment, was able to manage effectively the gummosis/foot rot of citrus and also exhibited the highest yield.
\end{abstract}

Keywords: Citrus foot rot/gummosis, Kinnow, Phytophthora nicotianae var. parasitica, T20 mutant Trichoderma asperellum

\section{Background}

Citrus is one of the most economic groups of horticulture crops worldwide and the second-largest fruit crop grown in over more than 50 countries commercially under different agro-climatic conditions (Naqvi 2003). The Kinnow (Citrus reticulata Blanco) is the hybrid of 2 important cultivars-“King" (C. nobilis) $\times$ "Willow leaf" (C. deliciosa) and is cultivated on a very large scale in Indian and Pakistan Punjab. In Punjab, it is mostly grown in Fazilka, Ferozpur, Hoshiarpur, Muktsar, Bathinda, and Faridkot districts. The area under Kinnow cultivation in 20182019 was 55.5 thousand ha with a yield of $237 \mathrm{q} / \mathrm{ha}$ and production of 1312.4 thousand tons of fruit in Punjab (Anonymous 2019).

\footnotetext{
* Correspondence: ajaychoudhary-pp@pau.edu

${ }^{1}$ Farm Advisory Services Center, Abohar, Punjab 152116, India

${ }^{2}$ Punjab Agricultural University, Ludhiana, Punjab 141004, India

Full list of author information is available at the end of the article
}

Foot rot/gummosis in citrus, caused by Phytophthora spp., is a serious and common disease and is responsible for significant economic losses. It attacks citrus species in nursery beds causing damping-off to fibrous root rot, crown rot, premature leaf fall, foot rot, and gummosis in mature orchards and infects almost every part of citrus plants (Shekari et al. 2012). Traditionally, foot rot/gummosis of citrus has been managed by chemical treatment but chemical control causes an imbalance in the microbial community, destroys the activity of beneficial microorganisms, causes chemical environmental pollution, toxicity in foods, and development of resistance in the pathogens.

In view of organic farming and sustainable agriculture, there is a need to investigate for successful biological control, which could, therefore, be a better choice for managing the disease (Gade and Lad 2018). Among the biocontrol agents, Trichoderma is the most exploited soil 
fungi due to its versatility, adaptability, and ease of handling in addition to its control mechanisms (Mukherjee et al. 2013). Trichoderma spp. have been focused on their antagonistic and mycoparasitic ability to reduce the disease incidence caused by phytopathogens (El-Sharkawya et al. 2018). They control the soil-borne pathogens through secretion of lytic enzymes (glucanases and cellulase), antimicrobial metabolites, competition, and induction of defense responses in target plants thereby stimulating the plant growth and enhancing crop productivity (Sallam et al. 2019).

Considering the catastrophe of the disease, the present investigations aimed to (a) isolate and characterize Trichoderma spp. associated with rhizospheric soil of Kinnow and (b) evaluate the biofungicidal formulated from potential potent native strains of Trichoderma spp. against the foot rot/gummosis of Kinnow to manage the disease effectively.

\section{Methods}

The present study was carried out at Kinnow mandarin orchards grown in the Abohar region (Punjab) over a period of 2 years (2016/17 and 2017/18).

\section{Sample collection and isolation of Phytophthora}

Soil samples were collected from Kinnow mandarin growing areas of Abohar region of Punjab state (India), which were affected by Phytophthora. Soil sampling was done up to the depth of $20 \mathrm{~cm}$ from gummosis affected Kinnow trees. The rhizospheric soil samples were collected from the 4 different directions around the infected trees and were mixed thoroughly to make a single sample. Along with the soil samples, the feeder roots were also collected for further study.

Three isolates (P1, P2, and P3) of Phytophthora spp. were isolated from the naturally infected plant materials by using the modified leaf-disk baiting technique of (Grimm and Alexander 1973). Fibrous roots of infected Kinnow plants along with their rhizospheric soil were placed in the $500 \mathrm{ml}$ glass beakers and the volume was made up to $500 \mathrm{ml}$ by adding sterile distilled water. Kinnow plant fibrous roots and soil suspension were allowed to settle down. Six to eight leaf piece sections $\left(10 \mathrm{~mm}^{2}\right)$ of rough lemon (C. jambhiri) were floated on the surface of the water in the beaker. Beakers were covered with black carbon paper and incubated for 4 days in a dark chamber at $20{ }^{\circ} \mathrm{C}$. Leaf sections were then removed and plated on CMA-PARPH medium. The CMA-PARPH medium consisted of antibiotic ingredients and corn meal agar as a selective medium. The antibiotic ingredients used were hymexazol $(0.08 \mathrm{~g})$, rifampicin $(0.012 \mathrm{~g})$, ampicillin $(0.25 \mathrm{~g})$, pimaricin $(0.01$ $\mathrm{g})$, and pentachloronitrobenzene $(0.01 \mathrm{~g})$. These were mixed in $100 \mathrm{ml}$ of DMSO (dimethyl sulfoxide) and subsequently added to $1 \mathrm{l}$ of autoclaved CMA medium. Furthermore, the plates were incubated in the darkness at $20^{\circ} \mathrm{C}$ for 7 days.

\section{Molecular identification of Phytophthora isolates DNA extraction of Phytophthora isolates}

Mycelial cultures of 3 isolates were grown in corn meal (CM) broth for 7 days and incubated at $20^{\circ} \mathrm{C}$. DNA of Phytophthora was extracted, using cetyl trimethyl ammonium bromide (CTAB), as described by Doyle and Doyle (1990). In the extraction buffer, 1\% polyvinylpyrrolidone and $0.2 \% \beta$-mercaptoethanol were used. DNA samples were evaluated both qualitatively and quantitatively by $0.8 \%$ agarose gel electrophoresis.

\section{PCR amplification Phytophthora isolates}

Extracted genomic DNA of Phytophthora isolates were amplified by PCR with genus-specific primers ( $\mathrm{Ph} 2$ 5"ATACTGTGGGGACGAAAGTC"-3 and ITS4 5“TCCTCCGCTTATTGATATGC"-3) (White et al. 1990). The PCR-amplification reactions were performed in a 11$\mu \mathrm{l}$ mixture containing $0.8 \mu \mathrm{l} \mathrm{MgCl}_{2}, 2.0 \mu \mathrm{l} \mathrm{PCR}$ buffer, $1.5 \mu \mathrm{l}$ dNTPs mix, $1.0 \mu \mathrm{l}$ of each primer, $4.0 \mu \mathrm{l}$ of template DNA, $0.4 \mu \mathrm{l}$ of Taq polymerase, and $0.3 \mu \mathrm{l}$ of sterile water. The PCR reaction was incubated in a programmable thermal cycler starting with an initial denaturation at $95^{\circ} \mathrm{C}$ for $5 \mathrm{~min}$, followed by 35 cycles of denaturation at $95^{\circ} \mathrm{C}$ for $30 \mathrm{~s}$; annealing at $50^{\circ} \mathrm{C}$ for $30 \mathrm{~s}$; extension of the DNA strands at $72^{\circ} \mathrm{C}$ for $1 \mathrm{~min}$; and a final extension step at $72{ }^{\circ} \mathrm{C}$ for $10 \mathrm{~min}$. Similarly, species-specific primers, Pn5 5-"GAACAATGCAACTTATTGGACGTTT"-3 and Pn6 5-“AACCGAAGCTGCCACCCTAC"-3 were used. PCR reaction was started with an initial denaturation at $95^{\circ} \mathrm{C}$ for $5 \mathrm{~min}$, followed by 35 cycles of denaturation at $95{ }^{\circ} \mathrm{C}$ for $30 \mathrm{~s}$; annealing at $55^{\circ} \mathrm{C}$ or $30 \mathrm{sec}$; extension at $72^{\circ} \mathrm{C}$ for $1 \mathrm{~min}$; and final extension at $72^{\circ} \mathrm{C}$ for $10 \mathrm{~min}$ (Ippolito et al. 2002). The amplified products of the PCR $(11 \mu \mathrm{l})$ were subjected to $1.5 \%$ agarose gel electrophoresis in $0.5 \mathrm{X}$ TBE buffer with the $100 \mathrm{bp}$ and $50 \mathrm{bp}$ ladder. The gel was visualized under UV light and the photographs were captured in the Gene Genius Gel Documentation system.

\section{Trichoderma culture}

\section{Sample collection from healthy Kinnow orchards}

Rhizospheric soil samples were collected by spade from healthy Kinnow orchards from different regions nearby Abohar (Punjab). These samples were then brought to the laboratory and stored at $2-4{ }^{\circ} \mathrm{C}$ to reduce their microbial activity.

\section{Isolation of Trichoderma}

A selective isolation method was employed to obtain highly effective antagonist fungus of the Trichoderma genera. The dilution plate method described by Hassan 
and El-Awady (2011) was used for the isolation of 25 isolates of Trichoderma. In this method, $10^{-5}$ serial dilutions of each soil sample were prepared in sterilized distilled water. Aliquots of each soil suspension $(0.5 \mathrm{ml})$ were transferred by triplicate to Trichoderma selected media (TSM) (Elad et al. 1981). The media plates were incubated at $25 \pm 1{ }^{\circ} \mathrm{C}$ for $96 \mathrm{~h}$. Furthermore, potato dextrose agar (PDA) media was used for purification and maintenance of the cultures and were preserved at $4{ }^{\circ} \mathrm{C}$.

\section{Molecular characterization of Trichoderma isolates DNA extraction of Trichoderma isolates}

The genomic DNA of 7 different isolates of Trichoderma (parent) was extracted from 7 days old mycelia growth on potato dextrose broth (PDB), using the CTAB, as described by Doyle and Doyle (1990). In the extraction buffer, $1 \%$ polyvinylpyrrolidone and $0.2 \% \beta$-mercaptoethanol were used. DNA samples were evaluated both qualitatively and quantitatively by using $0.8 \%$ agarose gel electrophoresis. For this study, the internal transcribed spacer (ITS) regions of the rDNA repeat from the $3^{\prime}$ end of the $18 \mathrm{~S}$ and the 5 'end of the $18 \mathrm{~S}$ gene were amplified by using primers i.e. ITS-1(5-“TCTGTAGGTGAACCTGCGG”-3) and ITS4(5-"TCCTCCGCTTATTGATATGC"-3) which were synthesized based on conserved regions of the eukaryotic rRNA gene (White et al. 1990).

\section{PCR amplification}

The PCR-amplifications were performed in a $11 \mu \mathrm{l}$ mixture containing $0.8 \mu \mathrm{l} \mathrm{MgCl}_{2}, 1.5 \mu \mathrm{l}$ dNTPs mix, $1.0 \mu \mathrm{l}$ of each primer, $4.0 \mu \mathrm{l}$ of template DNA, $0.4 \mu \mathrm{l}$ of Taq polymerase and $0.3 \mu \mathrm{l}$ of sterile water. For ITS amplification, cycle parameters included an initial denaturation at $95^{\circ} \mathrm{C}$ for $5 \mathrm{~min}$ followed by 35 cycles of denaturation at $94{ }^{\circ} \mathrm{C}$ for $1 \mathrm{~min}$; primer annealing at $62^{\circ} \mathrm{C}$ for $2 \mathrm{~min}$; primer extension at $72^{\circ} \mathrm{C}$ for $3 \mathrm{~min}$; and a final extension at $72{ }^{\circ} \mathrm{C}$ for $5 \mathrm{~min}$ (Hermosa et al. 2000). The amplified products of the PCR $(11 \mu \mathrm{l})$ were subjected to $1.5 \%$ Agarose Gel Electrophoresis in 0.5X TBE buffer at $5 \mathrm{~V} /$ $\mathrm{cm}$ for $60 \mathrm{~min}$ with $100 \mathrm{bp}$ ladder. The gel was visualized under UV light and the photographs were captured in the Gene Genius Gel Documentation system.

\section{Purification and nucleotide sequencing for identification of $P C R$ products}

The amplified PCR products were purified using Wiz$\operatorname{ard}^{\circ}$ SV Gel and PCR Clean-Up System (Promega, Inc.) as per the manufacturer protocol. Sequencing of ITS region of purified products was done, using both forward and reverse primers at SciGenom Labs (P) Ltd. Cochin (Kerala), India.

\section{DNA sequences analysis}

The sequences were extracted by using CHROMAS Lite 2.1.1 and these reads were aligned using DNA Baser assembler v.5.15.0 to generate a consensus sequence. The sequences were further subjected to Basic Local Alignment Search Tool (BLAST) software for comparison with the sequences of Trichoderma, previously submitted at National Centre for Biotechnology Information (NCBI) database (Druzhinina et al. 2005).

\section{Preparation of bioformulation of Trichoderma spp.}

The most effective 7 isolates of Trichoderma, i.e., parents and mutants, were formulated in talc powder. The talc powder (carrier) was autoclaved for $30 \mathrm{~min}$ at $15 \mathrm{psi}$ at $121^{\circ} \mathrm{C}$. The selected strains of Trichoderma spp. were grown as broth culture in the selective media for the preparation of formulation. Mycelial mat along with broth was homogenized and $600 \mathrm{ml}$ of this mixture was added to 1 $\mathrm{kg}$ of talc powder under aseptic conditions and dried. One percent carboxy methylcellulose (CMC) was added to the mixture as an adhesive (Aulakh et al. 2017).

\section{Orchard treatments}

A field experiment was laid out for the management of foot rot/gummosis on Kinnow mandarin (13-year-old Phytophthora infected orchard) at Abohar region (30 9' $0^{\prime \prime}$ North and 74 11' $0^{\prime \prime}$ East) of Punjab state (India) in randomized block design (RBD) during 2016-2017 and 2017-2018. Kinnow trees, which were grafted on rough lemon (Citrus jambhiri) rootstocks, planted in 1-acre block were used for this experiment.

Kinnow trees showing typical symptoms of Phytophthora infection, i.e., profuse oozing/bleeding of gum were chosen for the experiment. In each experiment, there were 3 repetitions per treatment in RBD. Trichoderma isolates and chemicals (Metalaxyl-M + Mancozeb) were used as soil treatment as well as applied as trunk paste and paint, respectively. The abovementioned treatments were done twice a year, i.e., during the months of February and July for the subsequent 2 years as described:

Seven native potent isolates of Trichoderma (parent and mutant) (Tables 1) and 2 standard checks (T. viride and $T$. harzianum) were used for the preparation of talcbased bioformulation.

a) Trichoderma talc-based bioformulation was applied as soil treatment as well as trunk paste treatment. The protocol is described as follows:

Soil treatment-100 g talc-based bioformulation of Trichoderma was mixed in $2.5 \mathrm{~kg}$ of FYM (Farm Yard Manure) and was kept for 7 days under shade for priming. The mixture was then applied to the feeder root zone (basin area) of infected trees. 
Table 1 Reference sequences retrieved for phylogenetic analysis from GenBank

\begin{tabular}{|c|c|c|c|c|c|}
\hline Isolate name & Genus & Species & Gene & Base pair & GenBank accession numbers \\
\hline $\mathrm{T} 2$ & Trichoderma & asperellum & ITS & 606 & MK210562.1 \\
\hline T3 & Trichoderma & asperellum & ITS & 602 & MK210429.1 \\
\hline T4 & Trichoderma & asperellum & ITS & 607 & MK210428.1 \\
\hline T16 & Trichoderma & asperellum & ITS & 602 & MK211208.1 \\
\hline T20 & Trichoderma & asperellum & ITS & 616 & MK210235.1 \\
\hline T21 & Trichoderma & asperellum & ITS & 600 & MK209012.1 \\
\hline T25 & Trichoderma & harzianum & ITS & 619 & MK209008.1 \\
\hline
\end{tabular}

Trunk paste treatment-A thick paste was prepared by adding sterilized water to talc-based bioformulation of Trichoderma and was applied to lesions on infected tree bark.

b) Standard chemical (Metalaxyl-M + Mancozeb) drenching near feeder root zone area (25 g in $10 \mathrm{l}$ of water) and applied as trunk paint ( $2 \mathrm{~g}$ in $100 \mathrm{ml}$ of linseed oil) on the lesion on the bark.

c) Untreated infected plants were maintained as control (Singh et al. 2015).

\section{Disease assessment and growth parameters evaluation}

Under the study field conditions, native strains of Trichoderma established themselves in the rhizospheric soil and root system of Phytophthora infected Kinnow trees, leading to an increase in feeder root density and reduction in the lesion size, thereby reducing the incidence of foot rot/ gummosis and increasing the number and yield of fruits.

The percent recovery of the infected area was assessed by noticing the variations in gummosis lesion size $\left(\mathrm{cm}^{2}\right)$ (Bairwa et al. 2015). Observations were recorded before and after the time of application for each treatment individually. The formula used is as follows:

Percent recovery lesion size $=$ (initial value - final value)/initial value $\times 100$

Feeder roots density was computed by using the water displacement method. (Harrington et al. 1994; Yesmin 2019). The number and fruit yield per plant were also recorded.

\section{Data analysis}

The whole data was in triplicates and was represented as mean \pm standard deviation. The variations in the results obtained concerning gummosis lesion size (arcsine transformation), feeder root, and plant growth parameters (number of fruits and weight) were analyzed by using computer software CPCS 1. The results were analyzed by using one-way analysis of variance (ANOVA) with SPSS software version 22 . The treatment means were separated by Duncan's multiple range test (DMRT) and were determined by the magnitude of $\mathrm{F}$ value $(p \leq 0.05)$. Correlations were observed between various parameters by using SPSS software version 22.

\section{Results}

Isolation and molecular characterization of Phytophthora

Three isolates (P1, P2, and P3) of Phytophthora were identified by isolation strategy and were identified up to genus and species level by using specific primers (Table 2). Genus-specific primers viz. Ph2 and ITS4 hybridized for all isolates of Phytophthora gave a single band of $700 \mathrm{bp}$ and species-specific primers viz. Pn5B and Pn6 gave a single band of $120 \mathrm{bp}$ (Fig. 1). Results obtained from molecular characterization confirmed that P1, P2, and P3 isolates of Phytophthora were P. parasitica var. nicotianae.

\section{Isolation and molecular characterization of Trichoderma}

By employing the isolation strategy, a total of 25 isolates of Trichoderma spp. were obtained from the Kinnow orchards, out of which 7 potent isolates were selected on basis of in vitro and biochemical analysis. All the 7 most potent strains of Trichoderma (Parent) were identified, using ITS Primers (ITS1 and ITS4). The ITS primers amplified a region of nearly $600 \mathrm{bp}$ from genomic DNA of Trichoderma isolates. Out of 7 isolates of Trichoderma, 6 (T2, T3, T4, T20, T16, and T21) showed 100\% similarity with Trichoderma asperellum and one isolate (T25) showed a resemblance with Trichoderma harzianum (Fig. 2). All sequences obtained in this study were submitted to NCBI GenBank and their accession numbers were obtained (Table 1).

The dendrogram was generated by unweight pairgroup methods with arithmetic mean (UPGMA), using BIO Profil 1D image software and NTSYSpc software (Fig. 3). Based on the results obtained, all 7 isolates were grouped into 2 main clusters, one cluster representing $T$. asperellum and the other T. harzianum. Furthermore, the $T$. asperellum cluster was sub-grouped into two: the first subgroup with 3 isolates and the second one also with 3 isolates. 
Table 2 Phytophthora genus and species specific primers sequence

\begin{tabular}{lllll}
\hline Primer name & Sequence $\left(\mathbf{5}^{\prime} \mathbf{-} \mathbf{3}^{\prime}\right)$ & Direction & Fragment size (bp) & Specificity \\
\hline Ph2 & ATACTGTGGGGACGAAAGTC & Forward & 700 & At genus level \\
ITS4 & TCCTCCGCTTATTGATATGC & Reverse & & At species level \\
Pn5B & GAACAATGCAACTTATTGGACGTT & Forward & 120 & \\
Pn6 & AACCGAAGCTGCCACCCTAC & Reverse & & \\
\hline
\end{tabular}

\section{Effect of application of Trichoderma isolates on feeder} roots density and gummosis lesion size of Kinnow mandarin under field conditions

For the maintenance of the feeder roots and lesion size recovery of foot rot/gummosis, 7 different isolates of Trichoderma (parent and mutant) and standard checks (Trichodema viride, T. harzianum, and Metalaxyl-M+ Mancozeb) were used in the experiment. With the establishment of abovementioned isolates of Trichoderma spp. in the root system of Kinnow plants over a period of 2 years, the treated plants showed significant improvement in feeder roots and lesion size recovery. In the treatment, T20 mutant showed the maximum volume of feeder roots $\left(0.0236 \mathrm{~cm}^{3}\right)$, followed by the T16 mutant $\left(0.0211 \mathrm{~cm}^{3}\right)$ over the control $\left(0.003 \mathrm{~cm}^{3}\right)$ (Table 3). These results were also testified by using Duncan's test and found to be statistically significant at 5\% level ( $p \leq$ 0.05). Maximum percent recovery of gummosis lesion size was noticed in treatment with T20 mutant (95.67\%), followed by treatment withT16 (82.80\%) over the control (- 39.91\%) (Table 4).

\section{Effect of application of Trichoderma isolates on the} number of fruits and yield under field conditions

Among all the isolates, the maximum number of fruits and weight of fruits per tree were noticed in the T20 mutant isolate (990.16), followed by the T16 mutant (931.17) as compared to the control (544.17) (Table 5).
In the case of yield, a similar trend was recorded as above, i.e., maximum in T20 mutant (168.83 kg/plant), followed by $\mathrm{T} 16$ mutant $(158.78 \mathrm{~kg} /$ plant $)$ as compared to control (92.63 kg/plant). The same was testified using Duncan's test, and results were found to be statistically significant in both the number of fruits and yield of Kinnow per plant under field conditions.

\section{Correlation analysis}

Pearson's coefficient of correlation was used to study the relationship between different parameters (Table 6). Correlation analysis in the study showed that feeder root density significantly $(p \leq 0.05)$ correlated with recovery of lesion size (0.9245). An increase in the number of fruits per plant was noticed with an increase in feeder root density (0.4462) and with an increase in recovery of lesion size (0.3261).

Similar trend was also observed in the weight of fruits per plant which showed a significant $(p \leq 0.05)$ correlation with feeder root density (0.8149), recovery of lesion size $(0.7171)$, and number of fruits per plant $(0.7082)$.

\section{Discussion}

The results of the above study clearly showed that the biocontrol agents like $T$. asperellum and T. harzianum recovered from Kinnow rhizospheric soil reduced the incidence of foot rot/gummosis and improved plant growth parameters in Kinnow under field conditions.

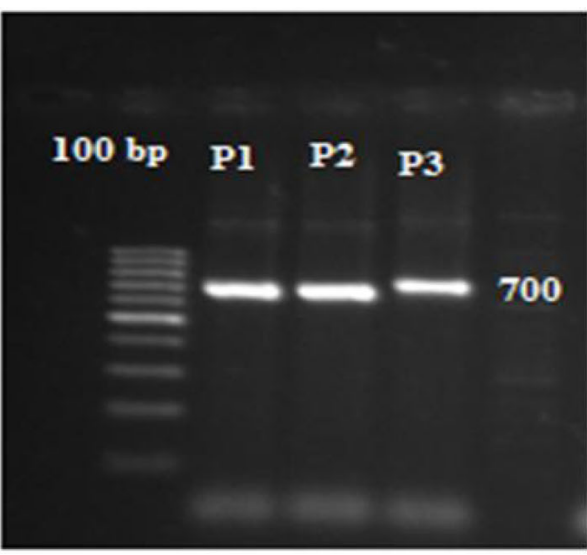

(Genus level)

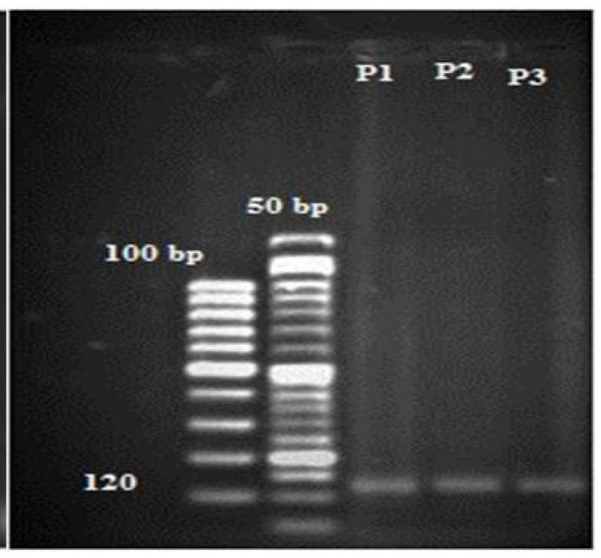

(Species level)

Fig. 1 DNA profile generated by Phytophthora genus and species by using specific primers, $M=100 \mathrm{bp}$ and $50 \mathrm{bp}$ 


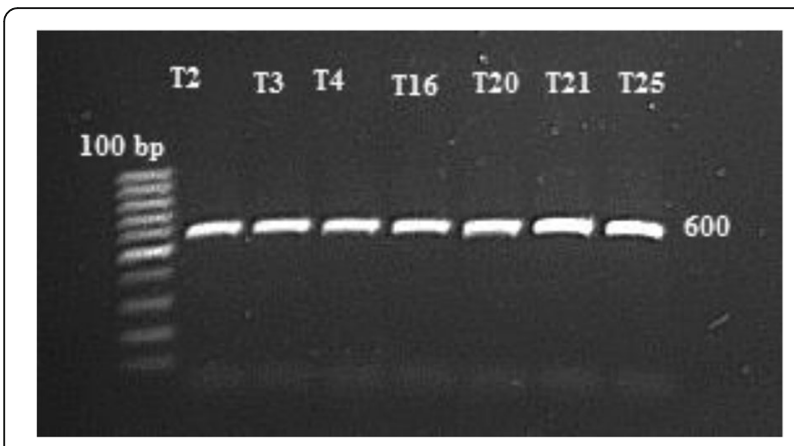

Fig. 2 DNA profile generated by ITS primers with Trichoderma isolates $M=100 \mathrm{bp}$ marker

Genus Trichoderma is used as biological control agent worldwide for the control of soil-borne pathogens, exhibits different modes of action such as growth regulation, competition by space and nutrients, decreases infection sites, and reduces the damage by pathogens that affect the development of the roots (Adnan et al. 2019).

In the present study, Trichoderma species, such as $T$. asperellum and T. harzianum were identified based on molecular approaches and have been frequently isolated from the rhizosphere worldwide (Jang et al. 2018). Molecular studies using the ITS region were able to classify each strain within the corresponding species. The results obtained with the studied isolation strategy proposed to agree with Baker and Cook's (1974) hypothesis that the isolation of potential antagonists against a specific pathogen by searching healthy plants in sites favorable to the development of the pathogen could prove to be effective. More recently, Andrade-Hoyos et al. (2020) isolated and molecularly characterized ten endophytic Trichoderma spp. strains against $P$. cinnamomi by use of internal transcribed spacer region and found minimum disease incidence in T. asperellum (T-AS2 and T-AS7) inoculated avocado seedlings. Ahmed (2015) used universal primers (ITS) for amplification of 18S rRNA gene fragment and identification of strain $T$. asperellum. Similarly, in the present study, ITS primers (ITS1\&4) were used to identify the Trichoderma spp.

The native strain of Trichoderma significantly decreased foot root/gummosis caused by $P$. nicotianae var. parasitica in Kinnow trees. This was supported by increasing percentage recovery of lesion size and feeder root density observed after Trichoderma bioformulation treatments than the untreated control. Since, fruit yield is the function of total fruit number and fruit weight, therefore higher fruit yield under Trichoderma application may be attributed to increased feeder root density and reduced lesion size.

That is why native strains of Trichoderma could promote the use of biological control agents over chemical fungicides. The results obtained in this study are concordant by numerous works demonstrating the preventive effectiveness of native strains of Trichoderma spp. against different species of Phytophthora. Mohamed et al. (2020) concluded that $T$. asperellum reduced the disease severity up to $10.7-26.5 \%$, and up to $26.6-36.6 \%$ under greenhouse and field conditions, respectively, by suppression of the pathogen as well as induction of plant systemic resistance. Similarly, Sanchez et al. (2019) found out that the regional strain of T. harzianum 1367 controlled the rot area caused by P. cactorum by $97 \%$, with the lowest average lesion area $\left(0.11 \mathrm{~cm}^{2}\right)$. Likewise, Promwee et al. (2017) concluded that indigenous strains of $T$. harzianum isolated from rhizosphere soil of rubber trees controlled $P$. palmivora better than the commercial Trichoderma strain, which could be due to environmental adaptation of the indigenous strains. Iuliana et al. (2017) showed that the inoculation of the T. asperellum T36 significantly reduced the percentage of dead plant seedlings and can be used as a biological alternative to pesticides for the control of $P$. parasitica in pepper seedlings. Our observations were also coincident with the

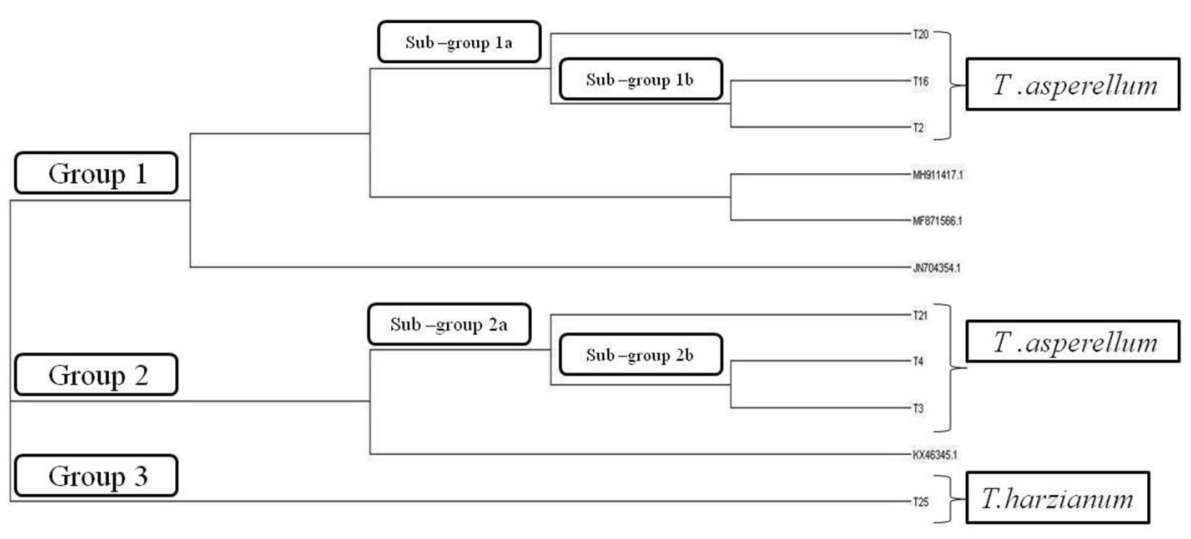

Fig. 3 Dendrogram showing similarity coefficient of seven Trichoderma isolates based on sequencing analysis 


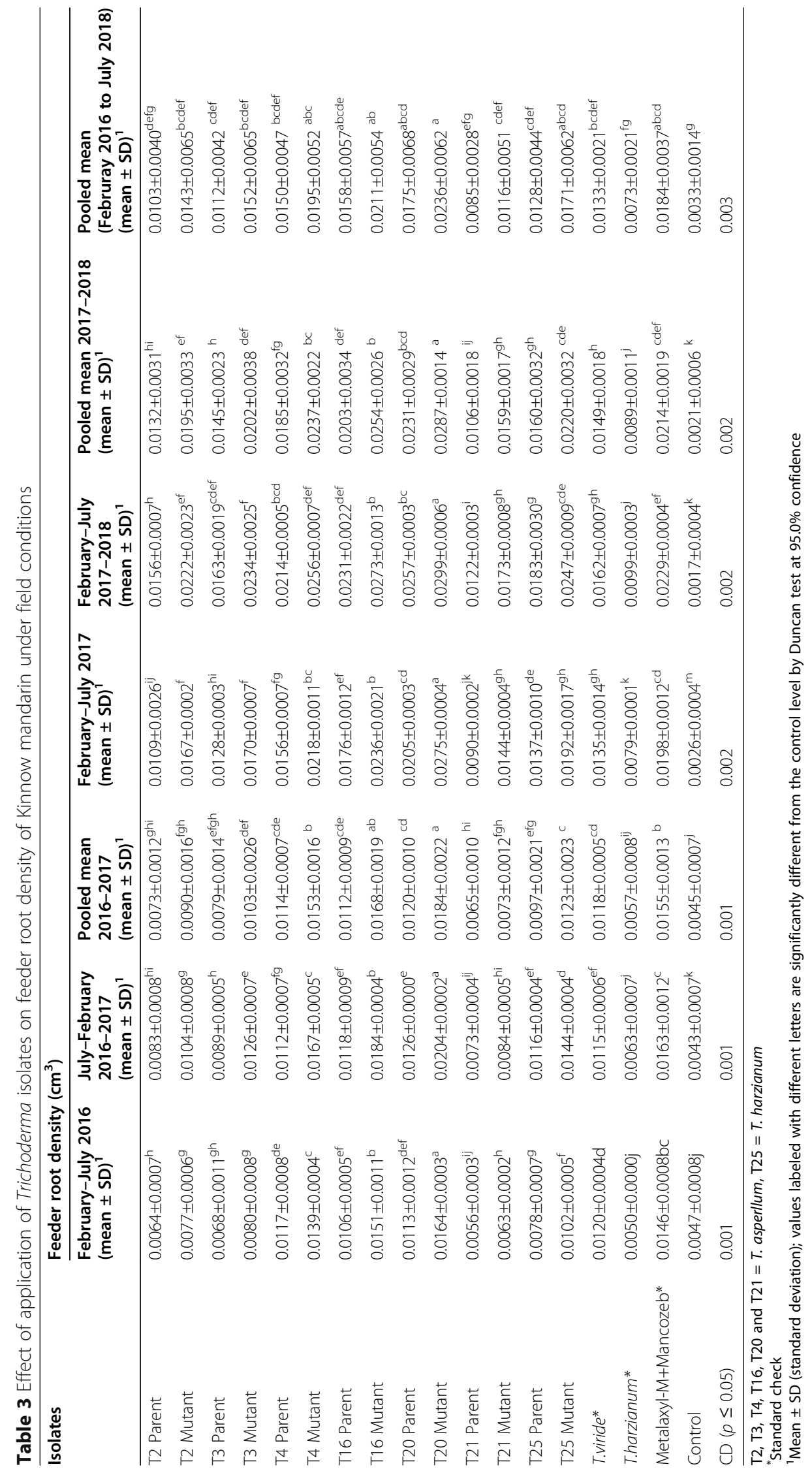


Table 4 Relative efficacy of Trichoderma parent and mutant isolates on percent recovery of lesion size

\begin{tabular}{|c|c|c|c|}
\hline \multirow[t]{2}{*}{ Isolates } & \multicolumn{3}{|c|}{ Recovery of lesion size (\%) } \\
\hline & 2016-2017 & $2017-2018$ & Total percent recovery \\
\hline T2 Parent & $17.82(24.94)$ & $26.46(30.27)$ & $44.28(41.60)$ \\
\hline T2 Mutant & $24.83(29.30)$ & $27.17(31.35)$ & $52.00(46.11)$ \\
\hline T3 Parent & $18.07(24.46)$ & $27.30(31.23)$ & $45.37(42.31)$ \\
\hline T3 Mutant & $25.84(29.70)$ & $30.13(33.08)$ & $55.97(48.63)$ \\
\hline T4 Parent & $25.24(30.10)$ & $30.41(33.25)$ & $55.65(48.30)$ \\
\hline T4 Mutant & $30.97(33.76)$ & 40.29 (39.30) & $71.26(57.75)$ \\
\hline T16 Parent & $31.45(34.04)$ & $34.36(35.70)$ & $65.82(54.28)$ \\
\hline T16 Mutant & 36.7137 .21 & $46.10(42.67)$ & $82.80(68.44)$ \\
\hline T20 Parent & $36.18(36.95)$ & $43.51(41.21)$ & $79.69(63.37)$ \\
\hline T20 Mutant & $44.45(41.79)$ & $51.38(45.77)$ & $95.67(75.81)$ \\
\hline T21 Parent & $18.16(23.62)$ & $21.63(27.46)$ & $39.79(38.87)$ \\
\hline T21 Mutant & $24.07(28.73)$ & $26.71(31.35)$ & $50.79(45.43)$ \\
\hline T25 Parent & $20.77(26.93)$ & $27.97(31.84)$ & $48.74(44.26)$ \\
\hline T25 Mutant & $26.87(31.01)$ & $32.85(34.74)$ & $59.71(50.68)$ \\
\hline T.viride* & $27.29(41.47)$ & $29.31(31.98)$ & $56.60(48.86)$ \\
\hline T.harzianum* & $17.98(25.07)$ & $20.07(26.59)$ & $38.05(38.04)$ \\
\hline Metalaxyl-M+Mancozeb* & $35.44(36.43)$ & $37.35(37.63)$ & $72.80(58.78)$ \\
\hline Control & $(-) 16.50(23.64)$ & $(-) 23.41(23.40)$ & $(-) 39.91(39.11)$ \\
\hline $\mathrm{CD}(p \leq 0.05)$ & 10.29 & 8.90 & 11.66 \\
\hline
\end{tabular}

$\mathrm{T} 2, \mathrm{~T} 3, \mathrm{~T} 4, \mathrm{~T} 16, \mathrm{~T} 20$ and $\mathrm{T} 21=T$. asperellum, $\mathrm{T} 25=T$. harzianum

*Standard checks

Figures in parenthesis is arc sine transformation

research of Singh et al. (2015) where the soil application of $T$. harzianum along with Bordeaux paste and copper oxychloride $(0.3 \%)$ spray improved percent recovery of gummosis lesion (54.70), fruit yield (58.5 kg/plant) and canopy volume $\left(16.9 \mathrm{~m}^{3}\right)$. The work of Melo et al. (2015) also supported that Trichoderma spp. isolates exhibited potential for use as biological control agents, both in vitro (by the production of antimicrobial compounds) and in the alfalfa seedling bioassay against $P$. nicotianae by affecting the production of sporangia and mycelia. Bairwa et al. (2015) also concluded that bioagents based treatment of stem painting with Bordeaux paste, followed by application of Trichoderma + Pseudomonas fluorescens with the carrier material FYM, significantly recovered lesion size (22.82\%), reduced feeder root rot index (24.39\%), increased fruit yield $(212.84 \mathrm{~kg} /$ tree $)$ and the number of fruits (1084 fruits/tree). Gade and Koche (2012) used the combination of Metalaxyl, Neem cake, Fosetyl-Al, Trichoderma spp., and P. fluorescens. They recorded a significant level of inhibition in population density, the intensity of root rot, and gummosis in Nagpur mandarin.

The capacity of isolates of Trichoderma sp. to promote growth in plants has been well documented (Sanchez et al. 2019). In the present experiment, significant differences were observed from the control without antagonist in the number of fruits and yield, the biggest difference being from $T$. asperellum T20 Mutant. This result would indicate that the effects of Trichoderma on the growth and vigor of the trees depend on the native rhizospheric Trichoderma isolates used and not on the species. Sukhada et al. (2011) proved that plants pre-inoculated with G. mosseae + T. harzianum, provided the best results when infected with $P$. parasitica var. nicotianae, with increased plant height, girth, and yield and also reduced disease severity over control without an antagonist. The work of Kean et al. (2010) also supported that Chaetomium and Trichoderma gave significantly disease control equal to the chemical fungicide (metalaxyl) when compared to the control.

The above facts depict that with the use of bioformulation of T20 mutant (T. asperellum) in Kinnow mandarin orchard, the disease could be managed effectively under field conditions. It led to an increase in the feeder root density that enhanced the recovery of lesion size and resulted in the highest fruit yield among various treatments. 
Table 5 Effect of application of Trichoderma isolates on number of fruits and yield under field conditions

\begin{tabular}{|c|c|c|c|c|c|c|}
\hline \multirow[t]{2}{*}{ Isolates } & \multicolumn{3}{|c|}{ Number of fruits per plant } & \multicolumn{3}{|c|}{ Weight of fruits per plant (kg) } \\
\hline & $\begin{array}{l}2016-2017 \\
(\text { mean } \pm \text { SD) })^{1}\end{array}$ & 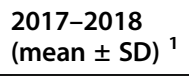 & $\begin{array}{l}\text { Pooled mean } \\
(\text { mean } \pm S D)^{1}\end{array}$ & $\begin{array}{l}2016-2017 \\
(\text { mean } \pm \text { SD) })^{1}\end{array}$ & $\begin{array}{l}2017-2018 \\
\left(\text { mean } \pm \text { SD) }{ }^{1}\right.\end{array}$ & $\begin{array}{l}\text { Pooled mean } \\
(\text { mean } \pm S D)^{1}\end{array}$ \\
\hline T2 Parent & $787.67 \pm 2.52^{9}$ & $796.67 \pm 5.77^{h}$ & $792.17 \pm 6.34^{9}$ & $130.75 \pm 0.42^{9}$ & $139.42 \pm 1.01^{h}$ & $135.08 \pm 4.80^{\mathrm{fgh}}$ \\
\hline T2 Mutant & $826.67 \pm 5.28^{e}$ & $840.00 \pm 10.00^{f}$ & $833.33 \pm 13.66^{\mathrm{ef}}$ & $137.23 \pm 2.54^{\mathrm{e}}$ & $147.00 \pm 1.75^{f}$ & $142.11 \pm 5.70^{\text {def }}$ \\
\hline T3 Parent & $808.67 \pm 3.21^{f}$ & $810.00 \pm 10.00^{g h}$ & $809.33 \pm 6.68^{\mathrm{gf}^{f}}$ & $134.24 \pm 0.53^{f}$ & $141.75 \pm 1.75^{\mathrm{gh}}$ & $137.99 \pm 4.27^{\mathrm{efg}}$ \\
\hline T3 Mutant & $853.33 \pm 5.77^{d}$ & $856.67 \pm 11.55^{\mathrm{e}}$ & $855.00 \pm 8.37^{\mathrm{de}}$ & $141.65 \pm 0.96^{\mathrm{d}}$ & $149.92 \pm 2.02^{e}$ & $145.79 \pm 4.74^{\text {cde }}$ \\
\hline T4 Parent & $812.33 \pm 2.52^{f}$ & $816.67 \pm 11.55^{9}$ & $814.50 \pm 7.84^{\mathrm{fg}}$ & $134.85 \pm 0.42^{f}$ & $142.92 \pm 2.02^{9}$ & $138.88 \pm 4.61^{\mathrm{efg}}$ \\
\hline T4 Mutant & $884.33 \pm 5.77^{c}$ & $890.00 \pm 10.00^{c d}$ & $887.17 \pm 7.94^{\mathrm{C}}$ & $146.80 \pm 0.96^{c}$ & $155.75 \pm 1.75^{\mathrm{cd}}$ & $151.27 \pm 5.06^{c}$ \\
\hline T16 Parent & $850.00 \pm 10.00^{d}$ & $858.33 \pm 2.89^{e}$ & $854.17 \pm 8.01^{\text {de }}$ & $141.10 \pm 1.66^{d}$ & $150.21 \pm 0.51^{e}$ & $145.65 \pm 5.11^{\text {cde }}$ \\
\hline T16 Mutant & $926.67 \pm 2.89^{b}$ & $935.67 \pm 4.04^{b}$ & $931.17 \pm 5.85^{b}$ & $153.83 \pm 0.48^{b}$ & $163.74 \pm 0.71^{b}$ & $158.78 \pm 5.46^{b}$ \\
\hline T20 Parent & $882.00 \pm 7.21^{c}$ & $885.00 \pm 8.66^{\mathrm{cd}}$ & $883.50 \pm 7.31^{c}$ & $146.41 \pm 1.20^{c}$ & $154.88 \pm 1.52^{\mathrm{cd}}$ & $150.64 \pm 4.79^{c}$ \\
\hline T20 Mutant & $988.67 \pm 2.31^{a}$ & $991.67 \pm 2.89^{\mathrm{a}}$ & $990.17 \pm 2.86^{\mathrm{a}}$ & $164.12 \pm 0.38^{\mathrm{a}}$ & $173.54 \pm 0.51^{\mathrm{a}}$ & $168.83 \pm 5.18^{a}$ \\
\hline T21 Parent & $750.00 \pm 10.00^{h}$ & $765.67 \pm 5.13^{i}$ & $757.83 \pm 11.14^{h}$ & $124.50 \pm 1.66^{h}$ & $133.99 \pm 0.90^{i}$ & $138.55 \pm 5.33^{h}$ \\
\hline T21 Mutant & $805.00 \pm 18.03^{f}$ & $820.00 \pm 10.00^{9}$ & $812.50 \pm 15.41^{\mathrm{fg}}$ & $133.63 \pm 2.99^{f}$ & $143.50 \pm 1.75^{9}$ & $149.25 \pm 5.83^{\mathrm{efg}}$ \\
\hline T25 Parent & $808.67 \pm 3.21^{f}$ & $816.33 \pm 10.97^{9}$ & $812.50 \pm 8.36^{\mathrm{fg}}$ & $134.24 \pm 0.53^{f}$ & $142.86 \pm 1.92^{9}$ & $129.25 \pm 4.89^{\mathrm{efg}}$ \\
\hline T25 Mutant & $874.00 \pm 5.29^{c}$ & $876.67 \pm 5.77^{d}$ & $875.33 \pm 5.16^{\mathrm{cd}}$ & $145.08 \pm 0.88^{c}$ & $153.42 \pm 1.01^{d}$ & $138.57 \pm 4.64^{\text {cd }}$ \\
\hline T.viride* & $881.67 \pm 2.89^{c}$ & $895.00 \pm 5.00^{c}$ & $888.33 \pm 8.16^{c}$ & $146.36 \pm 0.48^{c}$ & $156.63 \pm 0.88^{c}$ & $151.49 \pm 5.66^{c}$ \\
\hline T.harzianum* & $763.33 \pm 15.28^{h}$ & $773.33 \pm 5.77 i$ & $768.33 \pm 11.69^{h}$ & $126.71 \pm 2.54^{h}$ & $135.33 \pm 1.01^{i}$ & $131.02 \pm 5.03^{\mathrm{gh}}$ \\
\hline Metalaxyl M+Mancozeb* & $760.33 \pm 4.51^{\mathrm{h}}$ & $883.33 \pm 15.28^{\mathrm{cd}}$ & $821.83 \pm 68.12^{f}$ & $126.22 \pm 0.75^{h}$ & $154.58 \pm 2.67^{\mathrm{cd}}$ & $140.40 \pm 15.64^{\mathrm{ef}}$ \\
\hline Control & $578.33 \pm 11.50^{i}$ & $510.00 \pm 10.00^{j}$ & $544.17 \pm 38.65^{i}$ & $96.00 \pm 1.91^{i}$ & $89.25 \pm 1.75^{j}$ & $92.63 \pm 4.05^{i}$ \\
\hline $\mathrm{CD}(p \leq 0.05)$ & 13.98 & 14.26 & 23.06 & 2.32 & 2.55 & 4.25 \\
\hline
\end{tabular}

$\mathrm{T} 2, \mathrm{~T} 3, \mathrm{~T} 4, \mathrm{~T} 16, \mathrm{~T} 20$ and $\mathrm{T} 21=T$. asperllum, $\mathrm{T} 25=T$. harzianum

*Standard Check

${ }^{1}$ Mean \pm SD (standard deviation); values labeled with different letters are significantly different from the control level by Duncan test at $95.0 \%$ confidence

Table 6 Correlations (Pearson) between different parameters under field conditions

\begin{tabular}{lllll}
\hline Parameters & $\begin{array}{l}\text { Feeder root density } \\
\left(\mathbf{c m}^{3}\right)\end{array}$ & $\begin{array}{l}\text { Recovery of lesion size } \\
(\%)\end{array}$ & $\begin{array}{l}\text { Number of fruits per } \\
\text { plant }\end{array}$ & $\begin{array}{l}\text { Weight of fruits per plant } \\
(\mathbf{k g})\end{array}$ \\
\hline Feeder root density $\left(\mathrm{cm}^{3}\right)$ & 1 & & & \\
Recovery of lesion size $(\%)$ & 0.9245 & 1 & 1 \\
Number of fruits per plant & 0.4462 & 0.3261 & 0.7082 & 1 \\
$\begin{array}{l}\text { Weight of fruits per plant } \\
(\mathrm{kg})\end{array}$ & 0.8149 & 0.7171 & & \\
\hline
\end{tabular}




\section{Conclusion}

The outcome of the present study strengthens the ecofriendly approach of using the talc-based bioformulation of T20 Trichoderma asperellum, as soil application and trunk paste for management of foot rot/gummosis of citrus. By this approach, the use of Metalaxyl-M + Mancozeb can be avoided or reduced, thus reducing the chances of the development of resistant strains and nontarget inhibition of beneficial microflora.

\section{Abbreviations \\ CMA: Corn meal agar; CM: Corn meal; PARPH: Pimaricin, ampicillin, rifampicin pentachloronitrobenzene, and hymexazol; CTAB: Cetyl trimethyl ammonium bromide; TBE: Tris borate EDTA; TSM: Trichoderma selected media; PDA: Potato dextrose agar; PDB: Potato dextrose broth; ITS: Internal transcribed spacer; BLAST: Basic Local Alignment Search Tool; CMC: Carboxy methylcellulose; DMSO: Dimethyl sulfoxide}

\section{Acknowledgements}

Head of the Department of Plant Pathology, PAU, Ludhiana is duly acknowledged for providing financial assistance. All laboratories and field staff are also acknowledged for their support during the research.

\section{Authors' contributions}

The study was designed by all authors. AKC performed the molecular analysis. Interpretation of the data, manuscript writing, and reference settings were done by the first author AKC. Errors and grammatical mistakes in the manuscript were removed and edited by all authors (AKC, NS, and DS). Then, the final manuscript was read and approved by all authors. Author on reasonable request.

\section{Funding}

There are no funding sources for this manuscript.

\section{Availability of data and materials}

The datasets used and/or analyzed during the current study are available from the corresponding

\section{Declarations}

\section{Ethics approval and consent to participate}

This article does not contain any studies with human participants or animals.

\section{Consent for publication}

Not applicable.

\section{Competing interests}

The authors declare that they have no competing interests.

\section{Author details}

${ }^{1}$ Farm Advisory Services Center, Abohar, Punjab 152116, India. ${ }^{2}$ Punjab Agricultural University, Ludhiana, Punjab 141004, India. ${ }^{3}$ Department of Plant Pathology, Punjab Agricultural University, Ludhiana, Punjab 141 004, India.

Received: 11 February 2021 Accepted: 30 May 2021

Published online: 08 June 2021

\section{References}

Adnan M, Islam W, Shabbir A, Khan KA, Ghramh HA, Huang Z, Chen HY, Lu GD (2019) Plant defense against fungal pathogens by antagonistic fungi with Trichoderma in focus. Microb Pathog 129:7-18. https://doi.org/10.1016/j. micpath.2019.01.042

Ahmed (2015) Management of sheath blight of rice using native strains of biocontrol agents and cloning of the antifungal gene. Ph.D. dissertation, Punjab Agricultural University, Ludhiana, p 68

Andrade-Hoyos P, Silva-Rojas HV, Romero-Arenas O (2020) Endophytic Trichoderma Species Isolated from Persea americana and Cinnamomum verum Roots Reduce Symptoms Caused by Phytophthora cinnamomi in Avocado. Plants 9(9):1-17
Anonymous (2019) Statistical Abstract of Punjab Economic Advisor to Government of India, Chandigarh.

Aulakh SK, Singh N, Raina S, Choudhary AK, Buttar DS (2017) Shelf life study of the talc based bioformulation of the Trichoderma asperellum and Pseudomonas fluorescens, bioagents of plant pathogens. PI Dis Res 32(2):182-185

Bairwa SR, Srivastava AK, Kumar P, Meena RS, Koli CR (2015) Developing strategies for integrated management of Phytophthora root rot and gummosis in Kinnow mandarin (Citrus reticulata). Indian Phytopathol 68(1):101-105

Baker KF, Cook RJ (1974) Biological Control of Plant Pathogens. Freeman, San Francisco, p 442

Doyle JJ, Doyle JL (1990) Isolation of plant DNA from fresh tissue. Focus 12(1):13-15

Druzhinina IS, Kopchinskiy AG, Komon-Zelazowska M, Bissett J, Szakacs G, Kubicek CP (2005) An oligonucleotide barcode for species identification in Trichoderma and Hypocrea. Fungal Genet Biol 42(10):813-828. https://doi. org/10.1016/j.fgb.2005.06.007

Elad Y, Chet I, HenisY (1981) A selective medium for improving quantitative isolation of Trichoderma spp. from soil. Phytoparasitica 9(1):59-67. https://doi. org/10.1007/BF03158330

El-Sharkawya HHA, Rashadb YM, Ibrahimc AS (2018) Biocontrol of stem rust disease of wheat using arbuscular mycorrhizal fungi and Trichoderma spp. Physiol Mol Plant Pathol 103:84-91. https://doi.org/10.1016/j.pmpp.2018.05.002

Gade RM, Koche MD (2012) Integrated disease management for root rot and gummosis in Nagpur mandarin. Indian Phytopathol 65(3):272-275

Gade RM, Lad RS (2018) Biological Management of Major Citrus Diseases in Central India-A Review. Int J Curr Microbiol App Sci 6:296-308

Grimm GR, Alexander AF (1973) Citrus leaf pieces as traps for Phytophthora parasitica from soil slurries. Phytopathol 63:540-541

Harrington JT, Mexal JG, Fisher JT (1994) Volume Displacement Provides a Quick and Accurate Way To Quantify New Root Production. Tree Planters Notes 45:121-124

Hassan MM, El-Awady MA (2011) Isolation and molecular characterization of some Trichoderma spp. with high cellulase enzyme activities. Arab J Biotechnol 14(2):155-166

Hermosa MR, Grondona I, Iturriaga EA, Diaz-Minguez JM, Castro C, Monte E, Garcia-Acha I (2000) Molecular characterization and identification of biocontrol isolates of Trichoderma spp. Appl Environ Microbiol 66(5):18901898. https://doi.org/10.1128/AEM.66.5.1890-1898.2000

Ippolito A, Schena L, Nigro F (2002) Detection of Phytophthora nicotianae and P. citrophthora in citrus roots and soils by nested PCR. Eur J Plant Pathol 108(8): 855-868. https://doi.org/10.1023/A:1021208106857

Iuliana R, Florin O, Ana BLST, Mariana C, Diana CA, Mihaela B, Melania LA, Gelu V, Tatiana ES, Luiza J (2017) Evaluation of Trichoderma spp. as a biocontrol agent against Phytophthora parasitica. Scientific Bulletin. Series F Biotechnol 21:179-182

Jang S, Kwon SL, Lee H, Jang Y, Park MS, Lim YW, Kim C, Kim JJ (2018) New report of three unrecorded species in Trichoderma harzianum species complex in Korea. Mycobiology 46(3):177-184. https://doi.org/10.1080/122 98093.2018.1497792

Kean S, Soytong K, To-anun C (2010) Application of biological fungicides to control citrus root rot under field condition in Cambodia. Int J Agric Sci Technol 6(2):219-230

Melo JF, Martins EDS, Kupper KC (2015) Production of antifungal compounds by Trichoderma spp. to control Phytophthora nicotianae, causal agent of gummosis on citrus. Citrus R\&T 36(2):37-48

Mohamed BFF, Sallam NMA, Alamri SAM, Abo-Elyousr KAM, Mostafa YS, Hashem M (2020) Approving the biocontrol method of potato wilt caused by Ralstonia solanacearum (Smith) using Enterobacter cloacae PS14 and Trichoderma asperellum T34. Egypt J Biol Pest Cont 30:1-13

Mukherjee PK, Horwitz BA, Herrera-Estrella A, Schmoll M, Kenerley CM (2013) Trichoderma research in the genome era. Annu Rev Phytopathol 51(1):105129. https://doi.org/10.1146/annurev-phyto-082712-102353

Naqvi S (2003) Phytophthora disease of citrus and management strategies. Annu Rev Phytopathol 2:239-270

Promwee A, Yenjit P, Issarakraisila M, Intana W, Chamswarng C (2017) Efficacy of indigenous Trichoderma harzianum in controlling Phytophthora leaf fall (Phytophthora palmivora) in Thai rubber trees. J Plant Dis Prot 124(1):41-50. https://doi.org/10.1007/s41348-016-0051-y

Sallam NMA, Sallam A, Eraky A (2019) Effect of Trichoderma spp. on fusarium wilt disease of tomato. Mol Biol Rep 46(4):44-63

Sanchez AD, Ousset MJ, Sosa MC (2019) Biological control of Phytophthora collar rot of pear using regional Trichoderma strains with multiple mechanisms. Biol Control 135(8):124-134. https://doi.org/10.1016/j.biocontrol.2019.05.012 
Shekari ZB, Nazerian A, Saboroh OA (2012) Distribution, population density, and virulence of citrus gummosis and brown rot in mazandaran province. Iranian J Plant Pathol 48(1):11-12

Singh R, Dalal RPS, Bhatia SK (2015) Management of citrus foot rot/gummosis through integration of agronomic practices, bioagent and chemicals. Int J Plant Prot 43(3):350-353

Sukhada M, Manjula R, Rawal RD (2011) Evaluation of arbuscular mycorrhiza and other biocontrol agents against Phytophthora parasitica var. nicotianae infecting papaya (Carica papaya cv. Surya) and enumeration of pathogen population using immunotechniques. Biol Control 58(1):22-29. https://doi. org/10.1016/j.biocontrol.2011.03.013

White TJ, Bruns T, Lee S, Taylor J (1990) Amplification and direct sequencing of fungal ribosomal RNA genes for phylogenetics. In: Innis MA, Gelfand DH, Sninsky JJ, White TJ (eds) PCR Protocols: A guide to Methods and Applications. Academic Press, New York, p 315

Yesmin K (2019) Characterization of Phytophthora species associated with citrus foot rot and its management in Punjab. Ph.D.Thesis, Punjab Agricultural University, Ludhiana, p 25

\section{Publisher's Note}

Springer Nature remains neutral with regard to jurisdictional claims in published maps and institutional affiliations.

\section{Submit your manuscript to a SpringerOpen ${ }^{\circ}$ journal and benefit from:}

- Convenient online submission

- Rigorous peer review

- Open access: articles freely available online

High visibility within the field

- Retaining the copyright to your article

Submit your next manuscript at $\boldsymbol{\nabla}$ springeropen.com 